Jurnal THEOREMS (The Original Research of Mathematics) Vol. 5 No.2, Januari 2021. hal. 189-201

URL: http://jurnal.unma.ac.id/index.php/th

Naskah masuk: 10-12-2020 Naskah diperbaiki: 04-01-2021 Naskah diterima: 05-01-2021

\title{
PENGEMBANGAN BAHAN AJAR BERBANTUAN SOFTWARE MAPEL UNTUK MENINGKATKAN PEMAHAMAN KONSEP MATEMATIS MAHASISWA
}

\section{MAPEL SOFTWARE ASSISTED TEACHING DEVELOPMENT TO IMPROVE STUDENTS 'MATHEMATIC CONCEPT UNDERSTANDING}

\author{
Ummi Rosyidah ${ }^{1 *}$, Astri Setyawati², Aulia Ar Rakhman Awaludin ${ }^{3}$ \\ 1,2Universitas Nahdlatul Ulama Lampung, ${ }^{3}$ Universitas Indraprasta PGRI \\ Email: ummirosyium09@gmail.com \\ Hp: 0813-6618-0607
}

\begin{abstract}
ABSTRAK
Penelitian ini termasuk jenis penelitian pengembangan (research and development) yang terfokus pada pengembangan bahan ajar mata kuliah Aljabar Dasar yang bertujuan untuk meningkatkan pemahaman konsep matematis. Secara garis besar, model pengembangan yang dipakai dalam penelitian ini terdiri dari 3 tahapan, yaitu tahap pendahuluan, pengembangan dan evaluasi. Pada tahap pendahuluan, peneliti melakukan studi literatur dan analisis deskripsi mata kuliah dan identifikasi bahan ajar mata kuliah Aljabar Dasar. Bahan ajar yang dikembangkan diuji kevalidan, kepraktisan dan keefektifan. Dari hasil analisis validasi modul diperoleh 84,25 dengan kategori baik. Uji coba skala kecil diperoleh 38,7 dengan kategori baik. Hasil analisis kepraktisan bahan ajar selama empat kali pertemuan diperoleh rerata skor 25,25 dari skor idela 30 atau 84,17 dengan kategori sangat baik. Hasil analisis keefektifan rata-rata skor profil mengajar dosen yang menggunakan bahan ajar aljabar dasar berbasis pendekatan saintifik berbantu maple adalah 50,25 dari skor ideal 56 atau 89,73\% dengan kategori sangat baik. Rata-rata skor profil aktivitas belajar mahasiswa yang menggunakan bahan ajar aljabar dasar berbasis pendekatan saintifik berbantu maple adalah 44,5 dari skor ideal 52 atau 85,58\% dengan kategori sangat baik. Dari analisis hasil tes pemahaman konsep matematis diperoleh total rata-ratanya adalah 0,58 dengan kategori sedang, yang dapat disimpulkan bahwa bahan ajar mata kuliah aljabar dasar dengan pendekatan ilmiah (scientific approach) berbantuan software mapel dapat meningkatkan pemahaman konsep matematis mahasiswa program studi pendidikan matematika secara efektif.
\end{abstract}

Kata Kunci: Pembelajaran Saintifik, Pemahaman Konsep Matematis, Aljabar Dasar, Software Maple.

\begin{abstract}
This research is a type of research and development which focuses on developing teaching materials for Basic Algebra courses which aim to improve understanding of mathematical concepts. Broadly speaking, the development model used in this study consists of 3 stages, namely the preliminary, development and evaluation stages. In the preliminary stage, the researcher conducted a literature study and analysis of course descriptions and identified teaching materials for Basic Algebra courses. The teaching materials developed are tested for validity, practicality and effectiveness. From the results of the module validation analysis, it was obtained 84.25 with good categories. The small scale trial obtained 38.7 with good category. The results of the analysis of the practicality of teaching materials during four meetings obtained an average score of 25.25 from the ideal score of 30 or 84.17 in the very good category. The result of the analysis of the effectiveness of the average score of the teaching profile of the lecturers using basic algebra teaching materials based on the mapleassisted scientific approach is 50.25 from the ideal score of 56 or $89.73 \%$ with the very good category. The average score of the learning activity profile of students who use basic algebra teaching materials based on the maple-assisted scientific approach is 44.5 from the ideal score of 52 or $85.58 \%$ in the very good category. From the analysis of the results of the test for understanding mathematical concepts, the total average is 0.58 with the moderate category, which can be concluded that the teaching materials for basic algebra courses with a scientific approach assisted by subject software can improve mathematical conceptual understanding of students in the mathematics education study program. effectively.

Keywords: Scientific Learning, Mathematical Concept Understanding, Basic Algebra, Maple Software.
\end{abstract}


Jurnal THEOREMS (The Original Research of Mathematics) Vol. ... No. ..., Juli/Januari. hal. ...-.... URL: http://jurnal.unma.ac.id/index.php/th

Naskah masuk: $\quad$ Naskah diperbaiki: $\quad$ Naskah diterima: (diisi oleh redaksi)

\section{PENDAHULUAN}

Perkembangan pendidikan terjadi di semua negara seperti halnya di Indonesia. Berkembangnya pendidikan di Indonesia ditandai dengan berkembangnya kurikulum pendidikan. Pengembangan kurikulum pada dasarnya adalah meningkatkan dan mengefektifkan kurikulum yang sudah ada dengan cara mencari jalan yang lebih mudah, lebih cepat, lebih sederhana dan lebih efektif serta berusaha menghilangkan kelemahan yang terdapat pada kuruikulum sebelumnya.

Pada saat ini pengembangan kurikulum sekolah sangat dimungkinkan secara fleksibel untuk peningkatan kualitas pembelajaran, khususnya di sekolah. Matematika merupakan bagian dari kehidupan manusia. Sebagai suatu ilmu, matematika berperan dalam pengembangan ilmu yang lain, seperti fisika, kimia, arsitektur, teknik, geografi, ekonomi, dan sebagainya.

Aljabar Dasar merupakan salah satu mata kuliah wajib yang harus ditempuh mahasiswa pada strata pendidikan S1 Pendidikan Matematika. Kajian tentang matrik dalam mata kuliah ini merupakan dasar bagi perkembangan matematika secara umum. Kajian tentang matrik juga aplikatif terhadap konsep-konsep matematika lainnya seperti persamaan linear dan aritmatika sosial, sehingga mata kuliah ini cukup penting dalam pembelajaran matematika di lingkup perguruan tinggi dan menjadi bekal bagi para mahasiswa calon guru untuk menerapkan pembelajaran matematika di tingkat pendidikan SMP dan SMA.

Hal ini mengingat bahwa mahasiswa adalah calon guru yang kelak akan mentranfer ilmu kepada anak didik. Harapan ini tidak selalu sejalan dengan kondisi di lapangan, yaitu konsep dasar tentang matrik tidak selalu dapat tersampaikan kepada mahasiswa karena berbagai kendala, seperti minimnya bahan materi dan referensi, serta kurangnya kemampuan pemahaman konsep mahasiswa. Dari hasil observasi dengan mahasiswa peserta mata kuliah Aljabar Dasar Tahun Akademik 2017/2018, didapatkan bahwa mahasiswa masih kurang mantap dalam pengerjaan soal, seperti perkalian matrik dimensi besar, pencarian determinan dan invers apabila diberikan soal yang variatif.

Kesulitan mahasiswa ini diindikasikan karena kurangnya penguasaan konsep dari teori tersebut. Oleh karena belum adanya bahan ajar yang dapat mengantarkan mahasiswa pada pemahaman konsep inilah yang kemudian menjadi ide bagi peneliti untuk menyusun bahan ajar aljabar dasar dengan tujuan untuk memahamkan konsep mahasiswa. Pemahaman konsep yang baik akan berimplikasi pada peningkatan kemampuan mahasiswa dalam pemecahan masalah yang lebih luas baik tentang matrik maupun aplikasi dalam kajian matematika lainnya. Pemahaman (understanding) dapat diartikan menguasai sesuatu dengan pikiran [9]. Salah satu cara untuk meningkatkan pemahaman konsep matematis terhadap mata kuliah Aljabar Dasar adalah dengan menggunakan teknologi.

Pemanfaatan pembelajaran matematika pada perguruan tinggi menggunakan software-software seperti Maple, Matlab, fortran, Minitab, SPSS, Lindo dan lain- lain. Salah satu media yang dapat membantu mahasiswa untuk melakukan banyak eksplorasi adalah komputer dan perangkat lunaknya. Salah satu perangkat lunak komputer yang dapat digunakan untuk membantu pembelajaran Aljabar Dasar 
Jurnal THEOREMS (The Original Research of Mathematics) Vol. ... No. ..., Juli/Januari. hal. ...-.... URL: http://jurnal.unma.ac.id/index.php/th

Naskah masuk: $\quad$ Naskah diperbaiki: Naskah diterima: (diisi oleh redaksi)

adalah program software Maple. Bahan ajar Kalkulus II yang dikembangkan berbasis pendekatan sanitifik berbantu software maple dapat meningkatkan kemampuan penalaran mahasiswa secara efektif dan siginfikan [8].

Dari uraian diatas, penulis tertarik untuk melakukan penelitian terkait dengan "Pengembangan Bahan Ajar Mata Kuliah Aljabar Dasar Dengan Pendekatan Ilmiah (Scientific Approach) Berbantuan Software Maple Untuk Meningkatkan Pemahaman Konsep Matematis Program Studi Pendidikan Matematika". Berdasarkan uraian pada latar belakang diatas, dapat dirumuskan permasalahan sebagai berikut:

1. Apakah bahan ajar mata kuliah Aljabar Dasar berbasis pendekatan pembelajaran saintifik berbantuan software maple memenuhi kriteria kavalidan, kepraktisan dan keefektifan?

2. Apakah bahan ajar yang dikembangkan dapat meningkatkan kemampuan pemahaman konsep matematis mahasiswa secara efektif dan signifikan?

\section{A. Pendekatan Saintifik}

Pendekatan saintifik pertama kali diperkenalkan ke ilmu pendidikan Amerika pada akhir abad ke-19, sebagai penekanan pada pendekatan laboratorium kemiliteran yang mengarah pada fakta-fakta ilmiah. Pendekatan saintifik memiliki karakteristik doing science. Pendekatan saintifik juga berkembang pada matematika. Scientific Mathematics merupakan proyek Eropa yang mengaitkan antara matematika dan ilmu pengetahuan. Hal ini bertujuan untuk mengembangkan pembelajaran ke arah belajar yang komprehensif dan multidimensional mengenai isi dan konsep matematika. Ide dasarnya adalah untuk mendorong pembelajaran matematika dalam konteks ilmiah dan kegiatan peserta didik [11].

Pendekatan ini memudahkan pengajar atau pengembang kurikulum untuk memperbaiki proses pembelajaran, yaitu dengan memecah proses kedalam langkah-langkah atau tahapan-tahapan secara terperinci yang memuat instruksi untuk peserta didik melaksanakan kegiatan pembelajaran [9]. Belajar dengan berkegiatan akan berkontribusi terhadap pemahaman intuitif matematika peserta didik. Dengan kata lain,belajar matematika yang baik adalah mengalami atau berkegiatan.

Langkah-langkah pembelajaran scientific meliputi: a.Mengamati, b. Menanya, c. Menalar, d. Mencoba, e. Mengomunikasikan [5].

Berdasarkan langkah-langkah yang telah dijabarkan diatas, diduga bahwa dengan mengamati, menanya, menalar, mencoba dan mengomunikasikan dapat meningkatkan pemahaman mahasiswa karena dalam aplikasinya mahasiswa dituntun untuk melakukan pengamatan (melihat, membaca, mendengar)dari suatu objek atau benda.

\section{B. Pemahaman Konsep Matematis}

Pemahaman konsep merupakan suatu aspek yang sangat penting dalam pembelajaran, karena dengan memahami konsep siswa dapat mengembangkan kemampuannya dalam setiap materi pelajaran. Pemahaman konsep terdiri dari dua kata yaitu pemahaman dan konsep. Pembelajaran matematika yang efektif perlu pemahaman apa yang siswa ketahui, perlu pelajari, kemudian tantangan dan dukungan terhadap mereka untuk mempelajarinya dengan baik [12]. Pemahaman adalah penyerapan arti dari suatu materi pelajaran yang telah dipelajari. Pemahaman (Understanding) dapat 
Jurnal THEOREMS (The Original Research of Mathematics) Vol. ... No. ..., Juli/Januari. hal. ...-.... URL: http://jurnal.unma.ac.id/index.php/th

Naskah masuk: Naskah diperbaiki: Naskah diterima:

(diisi oleh redaksi)

diartikan menguasai sesuatu dengan pikiran [9]. Pemahaman merupakan perangkat standar program pendidikan yang merefleksikan kompetensi sehingga dapat mengantarkan siswa untuk menjadi kompeten dalam berbagai ilmu pengetahuan, sedangkan suatu konsep adalah suatu kelas atau kategori stimuli yang memiliki ciri-ciri umum [6].

Jadi pemahaman konsep adalah menguasai sesuatu dengan pikiran yang mengandung kelas atau kategori stimuli yang memiliki ciri-ciri umum. Sedangkan Matematika tidak ada artinya bila hanya dihafalkan, namun lebih dari itu dengan pemahaman siswa dapat lebih mengerti akan konsep materi pelajaran itu sendiri [1].

Dari pendapat beberapa ahli diatas maka pemahaman konsep matematis menginginkan mahasiswa mampu mengaplikasikan dan memahami konsep matematika yang telah diperoleh dalam kegiatan pembelajaran. Dengan memahami dan mengaplikasikan konsep tersebut maka mahasiswa dapat memecahkan masalah dalam proses pembelajaran ataupun kehidupan sehari-hari.

Adapun indikator pemahaman konsep matematika tersebut adalah sebagai berikut: (1) Menyatakan ulang sebuah konsep, yaitu kemampuan peserta didik untuk mengungkapkan kembali apa yang telah dikomunikasikan kepadanya, (2) Mengklasifikasikan objek-objek menurut sifat-sifat tertentu (sesuai dengan konsepnya), yaitu kemampuan peserta didik untuk dapat mengelompokkan objek menurut sifatsifatnya, (3) Memberikan contoh dan non contoh dari konsep, yaitu kemampuan peserta didik dapat membedakan contoh dan bukan contoh dari suatu materi yang telah dipelajari, (4) Menyajikan konsep dalam berbagai bentuk representasi matematis, yaitu kemampuan peserta didik menggambar atau membuat grafik, membuat ekspresi matematis, menyusun cerita atau teks tertulis, (5) Mengembangkan syarat perlu atau syarat cukup suatu konsep, yaitu kemampuan peserta didik mengkaji mana syarat perlu atau cukup suatu konsep yang terkait, (6) Menggunakan, memanfaatkan, dan memilih prosedur atau operasi tertentu, yaitu kemampuan peserta didik menyelesaikan soal dengan tepat sesuai dengan prosedur, dan (7) Mengaplikasikan konsep atau algoritma pemecahan masalah, yaitu kemampuan peserta didik menggunakan konsep serta prosedur dalam menyelesaikan masalah yang berkaitan dengan kehidupan seharihari [3]. Maka indikator yang digunakan dalam penelitian ini adalah

1. Menyatakan ulang sebuah konsep,

2. Mengklasifikasikan objek-objek menurut sifat-sifat tertentu (sesuai dengan konsepnya),

3. Memberikan contoh dan non contoh dari konsep,

4. Menyajikan konsep dalam berbagai bentuk representasi matematis,

5. Mengembangkan syarat perlu atau syarat cukup suatu konsep,

6. Menggunakan, memanfaatkan, dan memilih prosedur atau operasi tertentu,

7. Mengaplikasikan konsep atau algoritma pemecahan masalah

C. Software Maple

Beberapa manipulasi komputer, salah satunya program maple, mempunyai kemampuan untuk mengubah sususan representasi. Representasi yang berbeda seperti gambar, tabel, grafik dan simbol memungkinkan pengajar dapat menyajikan pengetahuan Matematika yang lebih luas bagi mahasiswa. Bagi 
Jurnal THEOREMS (The Original Research of Mathematics) Vol. ... No. ..., Juli/Januari. hal. ...-.... URL: http://jurnal.unma.ac.id/index.php/th

Naskah masuk: $\quad$ Naskah diperbaiki: $\quad$ Naskah diterima:

(diisi oleh redaksi)

para peserta didik, maple sangat cocok untuk dimanfaatkan sebagai "teman" belajar matematika, karena kecepatan, ketepatan dan kemudahannya dalam membantu menyelesaikan soal-soal aljabar, vektor, matriks, kalkulus, trigonometri dan sebagainya [4].

Maple adalah perngkat lunak matematika yang berbasi kompiter, yaitu sistem komputer aljabar yang mapu menyelesaiakan persamaan dalam bentuk solusi numerik dan simbolik. Maple dibuat oleh Wateloo Maple Sofware (WMS) yang cikal bakalnya berasal dapri para peneliti dari University of Wateloo, Canada, ditahun 1988. Didalamnya terdapat simbol, sintak dan semantik mirip bahasa pemograman. Maple mampu menyajikan pemrosesan simbolik dan visualisasi. Visualisasi persamaan matematika dapat disajika dalam berbagai variasi grafik simulasi modeling, bahkan animasi. Semuanya dapat dengan mudah dilakukan. Maple berjalan pada sistem operasi keluarga Windows dan cukup mudah untuk digunakan. Perintah-perintah seperti cut, copy, dan paste bisa menggunakan hotkey seperti di Windows.

Bahan ajar aljabar linear memberikan dampak yang positif serta efektif terhadap kemampuan belajar matematika khususnya kemampuan pemecahan masalah matematis mahasiswa dengan menggunakan maple [13].

Revolusi teknologi komputer yang semakin canggih dengan ukuran semakin kecil namun memiliki kapasitas dan kecepatan yang semakin besar, fungsinya semakin meluas seiring dengan berkembangnya temuan-temuan kreatif perangkat lunaknya (software) akan menyebabkan terjadinya revolusi dalam belajar [2]. Komputer yang semula sekadar untuk membantu memecahkan hitung- hitungan rumit kini bisa dipakai untuk olah kata, olah data, olah gambar, dan pangkalan data berbagai bidang kehidupan.

Inovasi pembelajaran dengan mengembangkan pembelajaran melalui Macromedia Flash dan Maple dan menghasilkan bahan ajar kalkulus II [7], dengan hasil penelitian ada pengaruh kemampuan komunikasi matematis mahasiswa calon guru yang memperoleh pembelajaran berbantuan Maple lebih baik daripada mahasiswa yang memperoleh pembelajaran langsung [7].

\section{METODE PENELITIAN}

Dalam penelitian ini, peneliti mengikuti langkah penelitian dan pengembangan (research and development) [10].

Mengadopsi dari langkah [10] tersebut, secara keseluruhan langkah langkah penggunaan penelitian dan pengembangan diringkas dalam tiga tahap, yaitu studi pendahuluan, pengembangan dan evaluasi. Dengan demikian pengembangan bahan ajar mata kulaih Aljabar Dasar dengan pendekatan pembelajaran saintifik ini akan dilaksanakan dalam tiga tahap, yaitu 1) studi pendahuluan, meliputi studi teori pendekatan pembelajaran saintifik, software maple serta teori pengembangan bahan ajar, teori kemampuan pemahaman konsep matematis; 2) tahap pengembangan meliputi penyusunan draft bahan ajar, pengkajian oleh ahli, ujicoba skala kecil terhadap beberapa mahasiswa dan dosen; 3) tahap evaluasi dan penyempurnaan bahan ajar.

Kegiatan pengembangan Pengembangan Bahan Ajar Mata Kuliah Aljabar Dasar Dengan Pendekatan Ilmiah (Scientific Approach) Berbantuan Software Mapel Untuk Meningkatkan Pemahaman Konsep 
Jurnal THEOREMS (The Original Research of Mathematics) Vol. ... No. ..., Juli/Januari. hal. ...-.... URL: http://jurnal.unma.ac.id/index.php/th

Naskah masuk: Naskah diperbaiki: Naskah diterima:

(diisi oleh redaksi)

Matematis Mahasiswa Program Studi Pendidikan Matematika tiga tahap, yaitu: 1) studi pendahuluan, meliputi studi teori pendekatan pembelajaran saintifik, software maple serta teori pengembangan bahan ajar, teori pemahaman konsep matematis; 2) tahap pengembangan meliputi penyusunan draft bahan ajar, pengkajian oleh ahli, uji coba skala kecil terhadap beberapa mahasiswa dan dosen; 3) tahap evaluasi dan penyempurnaan bahan ajar. Uraian deskripsi hasil ketiga tahap tersebut adalah sebagai berikut:

\section{Tahap Studi Pendahuluan}

Tahap studi pendahuluan meliputi analisis deskripsi mata kuliah dan silabus aljabar dasar, serta ideintifikasi struktur bahan ajar mata kuliah aljabar dasar. Analisis deskripsi Pemahaman Konsep Matematis serta identifikasi indikator Pemahaman Konsep Matematis Adapun uraiannya adalah sebagai berikut:

a. Hasil Analisis deskripsi mata kuliah dan silabus mata kuliah aljabar dasar

Mata kuliah ini mempelajari tentang mengaplikasikan konsepkonsep yang berkaitan dengan kalimat matematika tertutup dan kalimat matematika terbuka; persamaan dan pertidaksamaan linier; persamaan dan pertidaksamaan kuadrat dan grafiknya; program linier; sistem persamaan linier dengan menggunakan kaidah program linier dan fungsi objektif untuk menyelesaikan permasalahan seharihari; matriks dan determinan serta penggunaan matriks, determinan dan vektor serta penerapannya pada bidang matematika atau pada masalahmasalah nyata.

b. Hasil Identifikasi Struktur Bahan Ajar Mata Kuliah Aljabar Dasar

Berdasarkan analisi deskripsi dan silabus mata kuliah aljabar dasar dapat didefinisikan struktur bahan ajar kuliah aljabar dasar sebagai berikut:

Tabel 1. Struktur Bahan Ajar Kuliah Aljabar Dasar

\begin{tabular}{|c|c|}
\hline No & Topik Inti \\
\hline 1 & $\begin{array}{l}\text { Kalimat matematika tertutup atau } \\
\text { terbuka yang mempunyai nilai } \\
\text { benar atau salah. }\end{array}$ \\
\hline 2 & Persamaan linier \\
\hline 3 & Pertidaksamaan linier \\
\hline 4 & Persamaan kuadrat \\
\hline 5 & Pertidaksamaan kuadrat \\
\hline 6 & Barisan bilangan \\
\hline 7 & Deret bilangan \\
\hline 8 & $\begin{array}{l}\text { Fungsi linier dan fungsi kuadrat } \\
\text { serta grafiknya }\end{array}$ \\
\hline 9 & $\begin{array}{l}\text { Program linier untuk } \\
\text { menyelesaikan sistem persamaan } \\
\text { linier dua variabel }\end{array}$ \\
\hline 10 & $\begin{array}{l}\text { Program linier untuk } \\
\text { menyelesaikan sistem persamaan } \\
\text { linier tiga variabel }\end{array}$ \\
\hline 11 & $\begin{array}{l}\text { Fungsi objektif untuk } \\
\text { menyelesaikan permasalahan } \\
\text { sehari-hari yang berkenaan } \\
\text { dengan program linier. }\end{array}$ \\
\hline 12 & Matriks dan penggunaan matriks \\
\hline 13 & $\begin{array}{l}\text { Determinan dan penggunaan } \\
\text { determinan }\end{array}$ \\
\hline 14 & Vektor \\
\hline
\end{tabular}

Struktur bahan ajar aljabar dasar seperti yang ditampilkan pada Tabel 1 . tersebut digunakan untuk mengembangkan bahan ajar aljabar dasar dengan Pendekatan Ilmiah (Scientific Approach). Karena keterbatasan waktu, penyusunan bahan ajar ini difokuskan pada pembahasan persamaan dan pertidaksamaan, matriks, program linier dan vektor.

\section{Tahap Pengembangan}

Dalam tahap pengembangan bahan ajar ini, pelaksana kegiatan melakukan beberapa kegiatan yaitu penyusunan draft bahan ajar, pengkajian oleh ahli, revisi draft bahan ajar, uji coba skala kecil terhadap beberapa mahasiswa, 
Jurnal THEOREMS (The Original Research of Mathematics) Vol. ... No. ..., Juli/Januari. hal. ...-.... URL: http://jurnal.unma.ac.id/index.php/th

Naskah masuk: $\quad$ Naskah diperbaiki: $\quad$ Naskah diterima: (diisi oleh redaksi)

revisi produk bahan ajar dan uji cobaa pemakain produk dikelas.

a. Hasil Penyusunan Draft Bahan Ajar

Draft bahan ajar aljabar dasar disusun berdasarkan struktur bahan ajar aljabar dasar pada tabel 1. Draft bahan ajar disusun dengan sistematika halaman sampul halaman kata pengantar, halaman daftra isi, lembar kegiatan mahasiswa, latihan soal, dan daftar pustaka. Draft bahan ajar ini divalidasi dan dikaji oleh ahli.

\section{b. Hasil Pengkajian Ahli}

Setelah bahan ajar disusun, langkah berikutnya divalidasi oleh ahli sebanyak 3 orang. Validasi dilakukan dengan cara mengisi lembar validasi bahan ajar. Analisis hasil validasi disajikan dlaam tabel 1 berikut:

Tabel 2. Hasil Validasi Ahli Draft Bahan Ajar Aljbar Dasar

\begin{tabular}{|c|c|c|c|c|}
\hline No & $\begin{array}{c}\text { Aspek } \\
\text { Validasi } \\
\text { Modul }\end{array}$ & $\begin{array}{c}\text { Jmlh } \\
\text { Aspek }\end{array}$ & $\begin{array}{c}\text { Rata- } \\
\text { rata }\end{array}$ & Kategori \\
\hline 1 & $\begin{array}{c}\text { Kelayakan } \\
\text { Isi }\end{array}$ & 9 & 29,33 & Baik \\
\hline 2 & $\begin{array}{l}\text { Kelayakan } \\
\text { Penyajian }\end{array}$ & 13 & 41,7 & Baik \\
\hline \multirow[t]{2}{*}{3} & $\begin{array}{c}\text { Kelayakan } \\
\text { Bahasa }\end{array}$ & 4 & 13,3 & Baik \\
\hline & Jumlah & 26 & 84,25 & Baik \\
\hline & $\begin{array}{l}\text { Hasil } \mathrm{V} \\
\text { elayakan isi } \\
\text { alidasi } 29,33 \\
\text { engan kateg } \\
\text { ari } 3 \text { aspek } \\
\text { spek cakupa } \\
\text { oin, (2) as } \\
\text { erdiri dari } 2 \\
\text { erdiri dari } 4 \text { p }\end{array}$ & $\begin{array}{l}\text { lidasi } \\
\text { diperolel } \\
\text { dari sko } \\
\text { ri Baik. } \\
\text { elayakan } \\
\text { materi } \\
\text { ek kea } \\
\text { oin, (3) } \\
\text { oin. }\end{array}$ & $\begin{array}{l}\text { modul } \\
\text { rata-ra } \\
\text { maksir } \\
\text { Skor d } \\
\text { isi meli } \\
\text { terdiri } \\
\text { kuratan } \\
\text { aspek } r\end{array}$ & $\begin{array}{l}\text { pada } \\
\text { hasil } \\
\text { um } 45 \\
\text { eroleh } \\
\text { ati: (1) } \\
\text { dari } 3 \\
\text { materi } \\
\text { evansi }\end{array}$ \\
\hline
\end{tabular}

Hasil validasi modul pada kelayakan penyajian diperoleh rata-rata hasil validasi 41,7 dari skor maksimum 65 dengan kategori baik. Skor diperoleh dari 4 aspek dari kelayakan penyajian meliputi: (1) kelengkapan sajian terdiri dari 3 poin, (2) penyajian Informasi terdiri dari 4 poin, (3) penyajian pembelajaran terdiri dari 5 poin, (4) kemutakhiran materi terdiri dari 1 poin.

Hasil validasi modul pada kelayakan bahasa diperoleh rata-rata hasil validasi 13,5 dari skor maksimum 20 dengan kategori baik. Skor diperoleh dari 3 aspek kelayakan bahasa meliputi: (1) komunikatif terdiri dari 1 poin, (2) Dialogis dan interaktif terdiri dari 2 poin, (3) Kesesuaian dengan kaidah bahasa Indonesia terdiri dari 1 poin. Dengan demikian, bahan ajar tersebut layak diuji cobakan dalam skala kecil.

\section{a. Revisi Draft Bahan Ajar}

Berdasarkan hasil validasi ahli, draft bahan ajar mata kuliah aljabar dasar ini kemudian direvisi untuk selanjutnya digunakan dalam ujicoba skala kecil.

\section{b. Uji coba Bahan Ajar Skala Kecil}

Setelah bahan ajar divalidasi oleh ahli yang kemudian dilakukan revisi, disusun langkah berikutnya diuji coba dlaam skala kecil oleh 10 orang penilai yaitu mahasiswa. Ujicoba dilakukan dengan cara mengisi lembar penilaian bahan ajar. Analisis hasil uji coba skala kecil disajikan dengan hasil penilaian 10 mahasiswa pada bahan ajar dasirung pada uji coba terbatas. Ratarata nilai yang diperoleh adalah 38,7 dengan kategori baik. Dengan demikian bahan ajar tersebut layak diujicobakan dikelas.

\section{Tahap Evaluasi}

Sebelumnya telah dilakukan tahap studi pendahuluan dan studi pengembangan, langkah berikutnya adalah melakukan evaluasi terhadap produk bahan ajar yang sudah dihasilkan dan diujicobakan dikelas. Langkah ini dilakukan untuk menguji sejauh mana kepraktisan dan efektivitas dari bahan ajar yang digunakan. 
Jurnal THEOREMS (The Original Research of Mathematics) Vol. ... No. ..., Juli/Januari. hal. ...-.... URL: http://jurnal.unma.ac.id/index.php/th

Naskah masuk: $\quad$ Naskah diperbaiki: Naskah diterima: (diisi oleh redaksi)

a. Pengecekan Kepraktisan

Untuk memperoleh evaluasi kepraktisan bahan ajar ini, peneliti melakukan analisis wawancara kepada mahasiswa, serta menganalisis data yang diperoleh dari lembar evaluasi kepraktisan bahan ajar ketika digunakan didalam kelas.

1. Hasil Wawancara.

Berdasarkan hasil wawancara beberapa mahasiswa menunjukkan bahwa:

a) Materi lebih mudah dipahami

b) Suasana pada saat perkuliahan tidak membosankan

c) Mahasiswa mampu memahami Pembelajaran dengan pendekatan santifik

d) Memahami konsep lebih mudah

e) Mampu menggunakan aplikasi maple

f) Mempermudah dalam pengecekan hasil pekerjaan pada aplikasi Maple

2. Hasil Analisis Lembar Evalusai Kepraktisan

Hasil analisis data evaluasi kepraktisan diperoleh dengan memberikan lember evaluasi kepda observer dalam prose pembelajaran. Lembar evaluasi diisi selama 4 kali pertemuan yang kemudian dilah secara kualitatif. Hasil analisis data kepraktisan adalah sebagai berikut:

Tabel 3 Hasil Analisis Data Kepraktisan

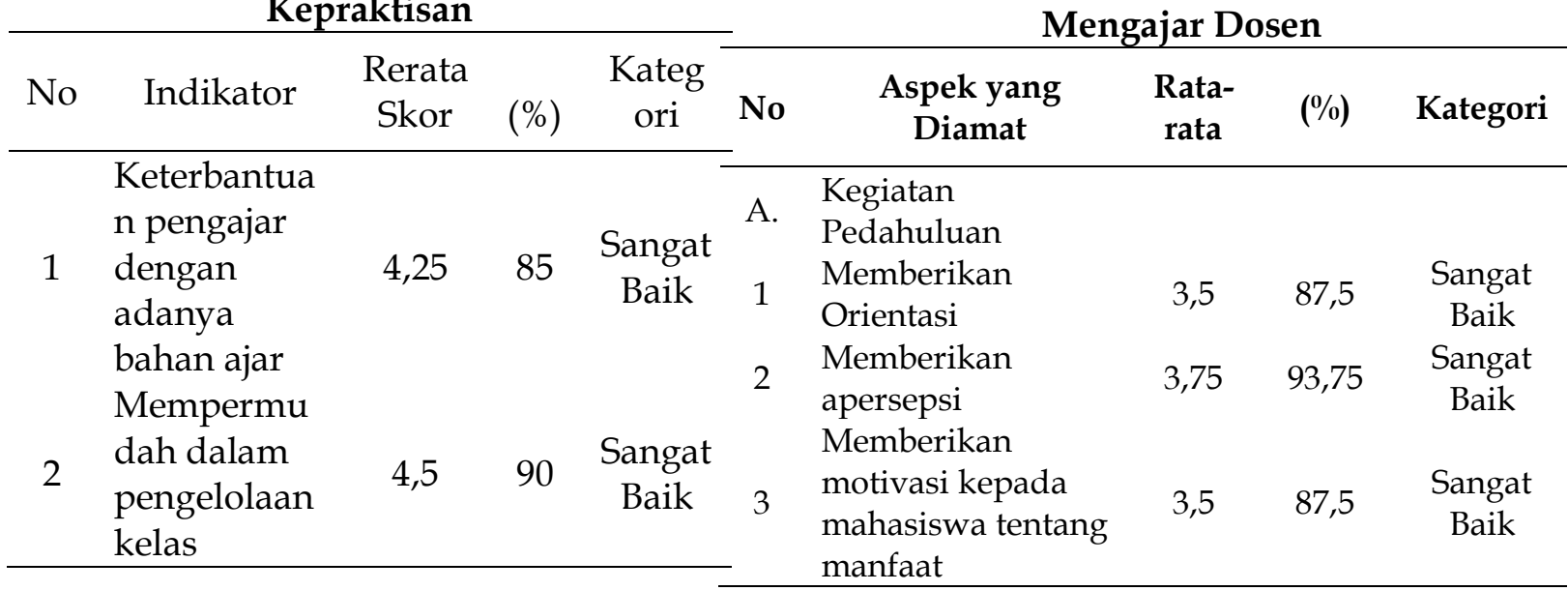


Jurnal THEOREMS (The Original Research of Mathematics) Vol. ... No. ..., Juli/Januari. hal. ...-....

URL: http://jurnal.unma.ac.id/index.php/th

Naskah masuk: $\quad$ Naskah diperbaiki: Naskah diterima: (diisi oleh redaksi)

mempelajari materi

atau yang lain)

Menyampaikan

4 tujuan

pembelajaran

3,5

Memberikan

gambaran umum

5 tentang materi dan

model yang akan

digunakan

B Kegiatan Inti

Memberikan waktu

kepada mahasiswa untuk memgamati

6 terlebih dahulu

Lembar Kerja

Mahasiswa yang

diberikan

Memberikan

kesempatan

kepada mahasiswa

7 untuk menanyakan

apa yang tidak

dipahami dari

LKM

Mempersilahkan

mahasiswa untuk

8 membuka buku

yang relevan

$3,75 \quad 93,75 \quad$ Sangat

$3,5 \quad 87,5 \quad \begin{gathered}\text { Sangat } \\ \text { Baik }\end{gathered}$

Total

$50,25 \quad 1256,25$

Rata-Rata Skor

$89,73 \quad \begin{gathered}\text { Sangat } \\ \text { Baik }\end{gathered}$

Tabel 5 Persentase Skor Profil Mengajar Dosen

\begin{tabular}{cc}
\hline Skor & Kategori \\
\hline $81,25<x \leq 100$ & Sangat Baik \\
$62,5<x \leq 81,25$ & Baik \\
$43,75<x \leq 62,5$ & Cukup \\
$25<x \leq 43,75$ & Kurang \\
\hline
\end{tabular}

Sanga
Baik

Sementara itu, profil mengajar dosen dengan menggunakan bahan ajar aljabar dasar berbasis pendekatan saintifik berbatu maple per aspek dalam kegiatan pembelajaran dapat diringkas sebagai berikut:

Tabel 6 Analisis Profil Mengajar Dosen Per Aspek

terkait materi

Membimbing

9 mahasiswa dalam

mengerjakan LKM

Membimbing

mahasiswa

10 menyimpulkan

hasil penemuan di

$3,75 \quad 93,75 \quad \begin{gathered}\text { Sangat } \\ \text { Baik }\end{gathered}$

Doek

No $\begin{gathered}\text { Aspek } \\ \text { yang } \\ \text { Diamat }\end{gathered} \quad \begin{gathered}\text { Skor } \\ \text { Total }\end{gathered}$

(\%) Kategori

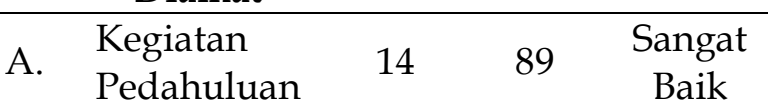

3,5 87,5 $\quad \begin{array}{r}\text { Sangat } \\ \text { Baik }\end{array}$

B Kegiatan

C $\begin{aligned} & \text { Kegiatan } \\ & \text { Penutup }\end{aligned} 14,67 \quad 91,67 \quad \begin{gathered}\text { Sangat } \\ \text { Baik }\end{gathered}$

LKM

Membantu

mahasiswa

11 mengomunikasikan

hasil pekerjaan

kelompok

C Kegiatan Penutup

12 Memberikan

Kesimpulan

Mengevalusai dan

13 merefleksi proses

penbelajaran

Memberikan tindak

14 lanjut pembelajaran (evaluasi, tugas

Sanga
Baik

$3,5 \quad 87,5 \quad \begin{array}{r}\text { Sangat } \\ \text { Baik }\end{array}$

Berdasarkan hasil obeservasi terhadap profil mengajar dosen dan datanya dianalisi seperti tabel, dapat disimpulkan beberapa hal sebagai berikut:

a. Rata-rata skor profil mengajar dosen yang menggunakan bahan ajar aljabar dasar berbasis pendekatan saintifik berbantu maple adalah 50,25 dari skor ideal 56 atau $89,73 \%$ dengan kategori sangat baik.

$3,75 \quad 93,75 \quad$ Sangat

$3,75 \quad 93,75 \quad \begin{gathered}\text { Sangat } \\ \text { Baik }\end{gathered}$

b. Rata-rata skor kegiatan pendahuluan profil mengajar dosen adalah 14 dari skor ideal 16 atau $89 \%$. 
Jurnal THEOREMS (The Original Research of Mathematics) Vol. ... No. ..., Juli/Januari. hal. ...-.... URL: http://jurnal.unma.ac.id/index.php/th

Naskah masuk: $\quad$ Naskah diperbaiki: Naskah diterima: (diisi oleh redaksi)

c. Rata-rata skor kegiatan inti profil mengajar dosen adalah 14,4 dari skor ideal 16 atau $90 \%$.

d. Rata-rata skor kegiatan penutup profil mengajar dosen adalah 14,7 dari skor ideal 16 atau 91,67\%.

\section{Profil Aktivitas Belajar Mahasiswa}

Lembar observasi profil aktivitas mahasiswa digunakan untuk memperoleh data aktivitas mahasiswa selama proses pembelajaran berlangsung. Berikut disajikan analisis data profil aktivitas belajar mahasiswa.

Tabel 7 Analisis Data Profil Aktivitas Belajar Mahasiswa

\begin{tabular}{|c|c|c|c|c|}
\hline No & $\begin{array}{l}\text { Aspek yang } \\
\text { Diamat }\end{array}$ & $\begin{array}{l}\text { Rata- } \\
\text { rata }\end{array}$ & $(\%)$ & $\begin{array}{r}12 \\
\text { Kategori }\end{array}$ \\
\hline
\end{tabular}

\begin{tabular}{|c|c|}
\hline \multirow[t]{2}{*}{ A. } & Kegiatan \\
\hline & $\begin{array}{l}\text { Pedahuluan } \\
\text { Kesianan }\end{array}$ \\
\hline 1 & $\begin{array}{l}\text { mahasiswa untuk } \\
\text { menerima } \\
\text { pembelajaran }\end{array}$ \\
\hline & $\begin{array}{l}\text { Respon } \\
\text { mahasiswa dalam }\end{array}$ \\
\hline 2 & $\begin{array}{l}\text { menerima } \\
\text { apersepsi dan } \\
\text { motivasi dari } \\
\text { dosen }\end{array}$ \\
\hline B & Kegiatan Inti \\
\hline 3 & $\begin{array}{l}\text { Memperhatikan } \\
\text { penjelsan materi }\end{array}$ \\
\hline 4 & $\begin{array}{l}\text { Bobot respon } \\
\text { mahasiswa }\end{array}$ \\
\hline & $\begin{array}{l}\text { Mahasiswa } \\
\text { mengamati }\end{array}$ \\
\hline 5 & $\begin{array}{l}\text { sejenak terleih } \\
\text { dahulu LKM yang } \\
\text { diberikan }\end{array}$ \\
\hline & $\begin{array}{l}\text { Mahasiswa } \\
\text { menanyakan apa }\end{array}$ \\
\hline 6 & $\begin{array}{l}\text { yang tidak } \\
\text { dipahami dari } \\
\text { LKM }\end{array}$ \\
\hline & Mahasiswa \\
\hline 7 & $\begin{array}{l}\text { menggunakan } \\
\text { buku yang relevan }\end{array}$ \\
\hline
\end{tabular}

3,75 93,75 Sangat

Baik

$3 \quad 75 \quad$ Baik

3,5 87,5 Sangat

Baik

$3 \quad 75 \quad$ Baik

$3 \quad 75 \quad$ Baik

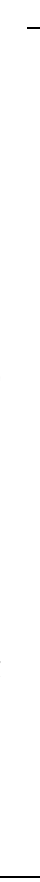

8
9
10
C
11
12
13

erkait materi

Mahasiswa

berbagi tugas

dengan baik

dalam

mengerjakan LKM

Mahasiswa

menyimpulkan

hasil penemuan

Mahasiswa

perawakilan

kelompok

mempresentasikan

hasil pekerjaan

LKM

C Kegiatan Penutup

1 Memberikan

Kesimpulan

Respon terhadap

evaluasi dan

refleksi proses

pembelajaran

Respon dalam

13 tindak lanjut

pembelajaran

Total

$3,5 \quad 87,5 \quad \begin{gathered}\text { Sangat } \\ \text { Baik }\end{gathered}$

3,75 93,75 $\begin{gathered}\text { Sangat } \\ \text { Baik }\end{gathered}$

$3,5 \quad 87,5 \quad$ Sangat

Skor Ideal

$3,75 \quad 93,75 \quad \begin{gathered}\text { Sangat } \\ \text { Baik }\end{gathered}$

$\begin{array}{ccc}3,5 & 87,5 & \begin{array}{c}\text { Sangat } \\ \text { Baik }\end{array} \\ 3 & 75 & \text { Baik }\end{array}$

$3,5 \quad 87,5 \quad \begin{gathered}\text { Sangat } \\ \text { Baik }\end{gathered}$

$44,5 \quad 1112,5$

$52 \quad 1300$

Rata-Rata Skor
Tabel 8 Persentase Skor Profil

Aktivitas Belajar Mahasiswa

\begin{tabular}{cc}
\hline Skor & Kategori \\
\hline $81,25<x \leq 100$ & Sangat Baik \\
$62,5<x \leq 81,25$ & Baik
\end{tabular}

43,75<x $\leq 62,5 \quad$ Cukup

$25<x \leq 43,75 \quad$ Kurang

Sementara itu, profil aktivitas belajar mahasiswa dengan menggunakan bahan ajar aljabar dasar berbasis pendekatan saintifik berbatu maple per aspek dalam kegiatan pembelajaran dapat diringkas sebagai berikut:

Tabel 9 Analisis Profil Aktivitas Belajar Mahasiswa Per Aspek 
Jurnal THEOREMS (The Original Research of Mathematics) Vol. ... No. ..., Juli/Januari. hal. ...-.... URL: http://jurnal.unma.ac.id/index.php/th

Naskah masuk: $\quad$ Naskah diperbaiki: $\quad$ Naskah diterima: (diisi oleh redaksi)

\section{yang Total}

Diamat

\begin{tabular}{clccc}
\hline A. & $\begin{array}{l}\text { Kegiatan } \\
\text { Pedahuluan }\end{array}$ & 14,5 & 90,63 & $\begin{array}{c}\text { Sangat } \\
\text { Baik } \\
\text { Sangat } \\
\text { B }\end{array}$ \\
$\begin{array}{l}\text { Kegiatan } \\
\text { Inti }\end{array}$ & 13,58 & 84,9 & $\begin{array}{c}\text { Baik } \\
\text { Cangat } \\
\text { Baik }\end{array}$ \\
\hline
\end{tabular}

Berdasarkan hasil obeservasi terhadap profil aktivitas belajar mahasiswa dan datanya dianalisi seperti tabel, dapat disimpulkan beberapa hal sebagai berikut:

a. Rata-rata skor profil aktivitas belajar mahasiswa yang menggunakan bahan ajar aljabar dasar berbasis pendekatan saintifik berbantu maple adalah 44,5 dari skor ideal 52 atau 85,58\% dengan kategori sangat baik.

b. Rata-rata skor kegiatan pendahuluan profil aktivitas belajar mahasiswa adalah 14,5 dari skor ideal 16 atau $90,63 \%$.

c. Rata-rata skor kegiatan inti profil aktivitas belajar mahasiswa adalah 13,58 dari skor ideal 16 atau $84,9 \%$.

d. Rata-rata skor kegiatan penutup profil aktivitas belajar mahasiswa adalah 13,33 dari skor ideal 16 atau 83,33\%.

3. Hasil Tes Pemahaman Konsep Matematis

Sebelum instrumen tes pemahaman konsep matematis digunakan, terlebih dahulu divalidasi isinya oleh ahli atau pakar. Selanjutnya instrumen tersebut diujikan kepada mahasiswa untuk memperoleh data pemahaman konsep matematis. Hasil analisis data pemahaman konsep matematis mahasiswa ditampilkan pada tabel berikut:
Tabel 10 Analisis Data Tes

Pemahaman Tes Matematis

\begin{tabular}{cccc}
\hline No & $\begin{array}{c}\text { N- } \\
\text { Gain }\end{array}$ & Kategori & $\begin{array}{c}\text { N- } \\
\text { Gain \% }\end{array}$ \\
\hline 1 & 0,50 & Sedang & 50,00 \\
2 & 0,55 & Sedang & 55,00 \\
3 & 0,57 & Sedang & 57,14 \\
4 & 0,67 & Tinggi & 66,67 \\
5 & 0,50 & Sedang & 50,00 \\
6 & 0,68 & Tinggi & 68,18 \\
7 & 0,79 & Tinggi & 78,95 \\
8 & 0,65 & Tinggi & 65,00 \\
9 & 0,29 & Rendah & 28,57 \\
10 & 0,59 & Sedang & 59,09 \\
Jumlah & 6 & & \\
Rerata & 0,58 & & 57,86 \\
& Sedang & & \\
\hline
\end{tabular}

Berdasarkan data pada tabel diatas, dapat disimpulkan bahwa total rata-rata pemahaman konsep matematis adalah 0,58 dengan kategori sedang. Dari 10 mahasiswa yang menyelesaikan tes pemahaman konsep matematis, dapat dikelompokkan seperti pada tabel berikut:

Tabel 11 Pemahaman Konsep Matematis Per Kategori

\begin{tabular}{ccccc}
\hline \multicolumn{5}{c}{ Pemahaman Konsep Matematis } \\
\hline Kategori & Tinggi & Sedang & Rendah & Jumlah \\
(Orang) & 4 & 5 & 1 & 10 \\
$(\%)$ & 40 & 50 & 10 & 100 \\
\hline
\end{tabular}

Berdasarakan tabel diatas, banyak mahasiswa dengan pemahaman konsep matematis berkategori rendah sebanyak 1 orang atau $(10 \%)$ dan tidak ada yang berkategori sangat rendah $(0 \%)$ dari 10 mahasiswa yang diujikan. Dengan demikian, dapat 
Jurnal THEOREMS (The Original Research of Mathematics) Vol. ... No. ..., Juli/Januari. hal. ...-.... URL: http://jurnal.unma.ac.id/index.php/th

Naskah masuk: $\quad$ Naskah diperbaiki: $\quad$ Naskah diterima: (diisi oleh redaksi)

disimpulkan bahwa bahan ajar mata kuliah aljabar dasar dengan pendekatan ilmiah (scientific approach) berbantuan software mapel dapat meningkatkan pemahaman konsep matematis mahasiswa program studi pendidikan matematika secara efektif.

\section{KESIMPULAN}

a. Bahan ajar yang dikembangkan memenuhi kriteria kevalidan, kepraktisan dan keefektifan.

b. Bahan ajar aljabar dasar yang dikembangkan berbasis pendekatan saintifik berbantu software maple dapat meningkatkan pemahaman konsep matematis secara efektif dan siginfikan.

c. Profil aktivitas belajar mahasiswa terhadap bahan ajar aljabar dasar yang dikembangkan berbasis pendekatan sanitifik berbantu software maple berkategori sangat baik.

d. Profil mengajar dosen terhadap bahan ajar aljabar dasar yang dikembangkan berbasis pendekatan sanitifik berbantu software maple berkategori baik.

\section{DAFTAR PUSTAKA}

[1] Alam, B. I. (2012). Peningkatan Kemampuan Pemahaman Dan Komunikasi Matematika Siswa Sd Melalui Pendekatan Realistic Mathematics Education (RME). Seminar Nasional Matematika dan Pendidikan Matematika FMIPA: UNY.

[2] Hardianto, D,. (2012). Pemanfaatan Software Komputer untuk Meningkatkan Kecerdasan Emosi (EQ) Anak. [online]. Tersedia: http://staff.uny.ac.id/sites/default /files/penelitian/Deni Hardianto,M.Pd./Pemanfaatan Software Komputer Untuk
Meningkatkan

Kecerdasan

Emosi.pdf.

[3] Kesumawati, Nila. (2010). Peningkatan Kemampuan Pemahaman, Pemecahan Masalah, dan Disposisi Matematis Siswa Melalui Pendekatan Pendidikan Matematika Realistik. Disertasi Tidak Dipublikasikan. Bandung : Program Pascasarjana UPI.

[4] Marjuni, Aris. (2006). Media Pembelajaran Matematika dengan Maplet. Yogyakarta: Graha Ilmu.

[5] Mulyasa. (2013). Pengembangan dan Implementasi Kurikulum 2013. Bandung: PT Remaja Rosdakarya.

[6] Oemar, H. (2008). Perencanaan Pengajaran Berdasarkan Pendekatan Sistem. Jakarta: Bumi Aksara.

[7] Paradesa, Retni, \& Ningsih, Y, L, (2017). Pembelajaran Matematika Berbantuan Maple Pada Mata Kuliah Kalkulus Integral Terhadap Kemampuan Komunikasi Matematis Mahasiswa. Jurnal Pendidikan Matematika RAFA, Vol. 03, No. 01, hlm.70 - 81.

[8] Rosyidah, U. \& Ayuwanti, I., (2018). Pengembangan Bahan Ajar Mata Kuliah Kalkulus II Materi Integral Dengan Pendekatan Ilmiah (Scientific Approach) Berbantuan Software Mapel Untuk Meningkatkan Kemampuan Penalaran Mahasiswa Program Studi Pendidikan Matematika. Laporan PDP Tidak Diterbitkan. Lampung: Universitas Nahdlatul Ulama Lampung.

[9] Sardiman. (2010). Interaksi \& Motivasi Belajar Mengajar. Jakarta: Rajawali Pers.

[10] Sugiyono. 2013. Metode Penelitian Pendidikan. Alfabeta: Bandung.

[11] Triyaningsih, Anisa Rara. (2015). Pengembangan Pengembangan Perangkat Pembelajaran Dengan Pendekatan Saintifik Pada Materi Trigonometri Untuk Peserta Didik Kelas XI SMA. Skripsi Tidak 
Jurnal THEOREMS (The Original Research of Mathematics) Vol. ... No. ..., Juli/Januari. hal. ...-.... URL: http://jurnal.unma.ac.id/index.php/th

Naskah masuk: $\quad$ Naskah diperbaiki: Naskah diterima: (diisi oleh redaksi)

Diterbitkan. Yogyakarta: FKIP

UNY.

[12] Turmudi. (2009). Landasan Filsafat Dan Teori Pembelajaran Matematika Berparadigma Eksploratif Dan Inisiatif. Jakarta: Leuser Cita Pustaka.

[13] Zulhendri, Hidayat, A., Zulfah,. (2019). Pengembangan Bahan Ajar Mata Kuliah Aljabar Linear Dengan Menggunakan Maple Program Studi Pendidikan Matematika Universitas Pahlawan Tuanku Tambusai, Journal Cendekia: Jurnal Pendidikan Matematika, Vol, 03, No. 02, hlm. 389 - 399. 